University of Nebraska - Lincoln

DigitalCommons@University of Nebraska - Lincoln

Civil and Environmental Engineering Faculty

Publications

$6-24-2014$

\title{
Effect of Composting on the Fate of Steroids in Beef Cattle
}

Manure

Shannon L. Bartelt-Hunt

Shannon Devivo

Leslie J. Johnson

Daniel D. Snow

William Kranz

See next page for additional authors

Follow this and additional works at: https://digitalcommons.unl.edu/civilengfacpub

Part of the Civil and Environmental Engineering Commons

This Article is brought to you for free and open access by the Civil and Environmental Engineering at DigitalCommons@University of Nebraska - Lincoln. It has been accepted for inclusion in Civil and Environmental Engineering Faculty Publications by an authorized administrator of DigitalCommons@University of Nebraska Lincoln. 


\section{Authors}

Shannon L. Bartelt-Hunt, Shannon Devivo, Leslie J. Johnson, Daniel D. Snow, William Kranz, Terry L. Mader, Charles Shapiro, Simon van Donk, David P. Shelton, David Tarkalson, and Tian C. Zhang 


\title{
Effect of Composting on the Fate of Steroids in Beef Cattle Manure
}

\author{
Shannon L. Bartelt-Hunt, * Shannon DeVivo, Leslie Johnson, Daniel D. Snow, William L. Kranz, Terry L. Mader, \\ Charles A. Shapiro, Simon J. van Donk, David P. Shelton, David D. Tarkalson, and Tian C. Zhang
}

In this study, the fate of steroid hormones in beef cattle manure composting is evaluated. The fate of 16 steroids and metabolites was evaluated in composted manure from beef cattle administered growth promotants and from beef cattle with no steroid hormone implants. The fate of estrogens (primary detected as estrone), androgens, progesterone, and the fusarium metabolite and implant $\alpha$-zearalanol was monitored in manure compost piles. First-order decay rates were calculated for steroid half-lives in compost and ranged from $8 \mathrm{~d}$ for androsterone to $69 \mathrm{~d}$ for 4 -androstenedione. Other steroid concentration data could not be fit to first-order decay models, which may indicate that microbial processes may result in steroid production or synthesis in composting systems. We demonstrate that composting is an effective strategy to remove steroid hormones from manure. Total steroid hormone removal in composted beef cattle manure ranged from 79 to $87 \%$.
Copyright $\odot$ American Society of Agronomy, Crop Science Society of America, and Soil Science Society of America. 5585 Guilford Rd., Madison, WI 53711 USA. All rights reserved. No part of this periodical may be reproduced or transmitted in any form or by any means, electronic or mechanical, including photocopying, recording, or any information storage and retrieval system, without permission in writing from the publisher.

J. Environ. Qual. 42:1159-1166 (2013)

doi:10.2134/jeq2013.01.0024

Received 24 Jan. 2013.

*Corresponding author (sbartelt2@unl.edu).
$\mathrm{T}$ HE ENVIRONMENTAL OCCURRENCE of endocrinedisrupting compounds, such as steroid hormones, is a public health concern due to their observed reproductive impacts on aquatic organisms, including abnormal expression of secondary sex characteristics (Seki et al., 2006) and abnormal gonadal development resulting in intersex fish (Tetreault et al., 2011). A primary route for the introduction of steroid hormones into the environment is biosolids and wastewater from municipal and agricultural sources. Agricultural sources, including wastewater lagoons at concentrated animal feeding operations (Fine et al., 2003; Hutchins et al., 2007; Zheng et al., 2008; Bartelt-Hunt et al., 2012), land application of manure to agricultural fields (Nichols et al., 1997; Finlay-Moore et al., 2000; Dutta et al., 2010; Gall et al., 2011), and runoff from animal feedlot surfaces (Mansell et al., 2011; Bartelt-Hunt et al., 2012), constitute an important source of steroid hormones to the environment.

Concentrated animal feeding operations in the United States generate an estimated 1.2 to 1.37 billion tons of manure each year (USEPA, 2004). Livestock manure typically contains endocrine-disrupting compounds because all livestock produce endogenous steroids, and some, such as beef cattle, are also routinely administered steroid hormones as growth promotants (Kolok and Sellin, 2008). The benefits of land application of manure include increased soil productivity, increased soil organic matter, improved water infiltration, and reduced potential for soil erosion. Furthermore, land-applied manure constitutes a source of valuable fertilizer nutrients. Despite these benefits, overapplication of manure to agricultural fields can result in water quality impairment in adjacent surface waters that can include nutrients, pathogens, and other trace level contaminants (Burkholder et al., 2007).

Strategies such as manure composting may reduce the concentration of trace organic compounds present in manure. Composting is a self-heating aerobic process in which manure

\footnotetext{
S.L. Bartelt-Hunt, S. DeVivo, and T.C. Zhang, Dep. of Civil Engineering, Univ. of Nebraska-Lincoln, Peter Kiewit Institute, Omaha, NE 68182-0178; D.D. Snow, School of Natural Resources, Univ. of Nebraska-Lincoln, Lincoln, NE 68583-0844; Leslie Johnson, W. L. Kranz, C.A. Shapiro, and D.P. Shelton, Northeast Research and Extension Center, Univ. of Nebraska-Lincoln, Concord, NE 68728-2828; T.L. Mader, Mader Consulting, LLC, 9301 Valaretta Dr., Gretna, NE 68028; S.J. van Donk, West Central Research and Extension Center, Univ. of Nebraska-Lincoln, North Platte, NE 69101-7751; D.D. Tarkalson, USDA-ARS, Northwest Irrigation and Soils Research Lab., Kimberly, ID. Assigned to Associate Editor Kang Xia.
}

Abbreviations: APPI, atmospheric pressure photoionization; MRM, multiple reaction monitoring. 
is piled into windrows and turned occasionally to achieve thermophillic temperatures (Hakk and Sikora, 2011). Manure composting has been demonstrated to reduce the concentration of nutrients and veterinary pharmaceuticals present in manure (Kim et al., 2012; Derby et al., 2011; Arikan et al., 2009; Ramaswamy et al., 2010; Bao et al., 2009). A limited number of studies have reported the influence of composting on steroid hormone concentrations in manure. Hakk et al. (2005) reported a decrease in the amount of water-soluble $17 \beta$-estradiol and testosterone extracted from poultry litter after composting. A later laboratory composting study demonstrated that at least $85 \%$ of $17 \beta$-estradiol in poultry litter was degraded or mineralized, with the primary metabolite being estrone (Hakk and Sikora, 2011). Derby et al. (2011) documented the occurrence of $17 \beta$-estradiol and estrone during a field study of swine manure composting and determined that estrone was the dominant estrogen present in swine manure. This study found that total estrogenicity in the compost decreased by nearly $80 \%$ over the study period (Derby et al., 2011). To our knowledge, there are no other studies that have examined the influence of composting on steroid hormone occurrence in other types of animal manures, such as beef cattle or dairy manure. In addition to $17 \beta$-estradiol, estrone, and testosterone, the behaviors of additional endogenous or exogenous steroid hormones or metabolites have not been evaluated in animal manure composting systems. To better characterize the effect of composting on levels of steroid hormones in manure, we conducted a field study in which beef cattle manure containing synthetic and endogenous steroid hormones was composted for a 76-d period. The concentration of 16 steroid hormones and metabolites in the manure was measured over time, and the influence of composting on the occurrence of steroid hormones in beef cattle manure was evaluated.

\section{Materials and Methods Manure Collection}

Beef cattle manure was collected from confined animal pens at the University of Nebraska-Lincoln Haskell Agricultural Laboratory in Concord, Nebraska. Heifers were divided equally into two groups: a treatment group in which animals were administered subcutaneous implants and feed additives containing steroid hormones and a control group with no synthetic hormone administration. In the treated group, the animals received an implant containing $36 \mathrm{mg}$ of $\alpha$-zeralanol. After $35 \mathrm{~d}$, the same animals received an implant containing $140 \mathrm{mg}$ of trenbolone acetate and $14 \mathrm{mg}$ of $17 \beta$-estradiol benzoate. Animals in the treated group also received $0.45 \mathrm{mg}$ of melengestrol acetate per animal per day via feed from Day 7 to the end of the study period. Additional information regarding the generation of beef cattle manure can be found in BarteltHunt et al. (2012). At the conclusion of the feeding period, the animals were removed from the pens, and all soil and manure was mechanically scraped from the feedlot pens down to the clay layer. The soil and manure scraped from the pens holding cattle treated with growth promotants was held separately from that generated in the control pens. Three compost piles were created from each manure source for a total of six compost piles, and each pile contained approximately $5000 \mathrm{~kg}$ of manure and soil.
Alfalfa hay was added to the compost piles at approximately $8 \%$ by weight to serve as a bulking agent and to increase the C:N ratio. Initially, water was added to the compost piles, and the moisture content in the compost piles was 25 to $45 \%$ by weight. The piles were turned as necessary to introduce oxygen into the compost piles.

\section{Sampling}

The compost piles were monitored for oxygen and temperature using a Compost Pro datalogger according to the manufacturer's instructions. Moisture content was determined gravimetrically. Each pile was sampled every 2 wk for the concentration and types of steroid hormones present in the manure. Manure samples were obtained by taking six 100-g subsamples from the center of each pile. These subsamples were mixed together in a stainless steel bucket, and a 250-g composite sample was collected in a foil-lined zipper bag and stored frozen at $-20^{\circ} \mathrm{C}$ for hormone analysis. A 100 -g sample was collected for moisture content analysis.

\section{Sample Extraction and Steroid Hormone Analysis}

Steroid hormones were extracted and analyzed using a newly developed instrumental method (Snow et al., 2013), which used liquid chromatography-tandem mass spectrometry with atmospheric pressure photoionization (APPI). All reagents used in steroid analysis were purchased from Fisher Scientific in the highest purity available (Optima, Thermofisher Scientific). Pure steroid standards, including 17 $\beta$-estradiol, estrone, estriol, testosterone, 4-androstenedione, androsterone, $17 \beta$-trenbolone, and progesterone, were purchased from Sigma-Aldrich or Acros Chemicals, and $17 \alpha$-trenbolone was obtained from Hayashi Pure Chemical Industries. Internal standards included testosterone- $\mathrm{d}_{3}$ (Sigma Aldrich) and ${ }^{13} \mathrm{C}_{6}-$ estradiol (Cambridge Isotopes).

Compost samples were extracted using microwave-assisted solvent extraction (Snow et al., 2013; Camel, 2000; Labadie et al., 2007; Matejícek et al., 2007). Briefly, 2 to $3 \mathrm{~g}$ of sample was weighed into a $10-\mathrm{mL}$ Teflon microwave digestion vessel and mixed with $1 \mathrm{mg}$ of butylated hydroxytoluene and 5 $\mathrm{mL}$ of high purity methanol. Twenty-five nanograms of testosterone- $\mathrm{d}_{3},{ }^{13} \mathrm{C}_{6}$-estradiol, and $17 \alpha$-methyltestosterone (surrogate) was added by pipette, and the contents were vortexed before microwaving in a CEM MARS Xpress microwave at $1000 \mathrm{~W}$ for $10 \mathrm{~min}$. Surrogate recovery averaged $97 \pm 23 \%$ over all samples. No clean-up by solvent or solidphase extraction was used.

Quantification of steroids in manure extracts used liquid chromatography tandem mass spectroscopy with APPI and multiple reaction monitoring (MRM) on a Quattro Micro triple quadrupole mass spectrometer (Waters Corp.) with an IonSabre APCI/APPI source (Snow et al., 2013). The method uses a gas-phase selective ionization with a toluene dopant compound and is optimized for simultaneous detection of estrogens, androgens, and steroid-like compounds using positive ion MRM. Minimal sample processing and cleanup was required, and reduced matrix interferences were observed in comparison to methods using electrospray ionization (Snow et al., 2013). A Thermo HyPurity C18 column (250 $\times 2 \mathrm{~mm}, 5 \mu \mathrm{m}, 50^{\circ} \mathrm{C}$ ) was used for gradient separation at a 


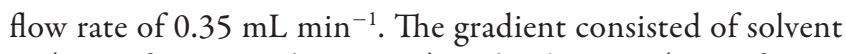
A ( $0.1 \%$ formic acid in water) and solvent B $(0.1 \%$ formic acid in methanol), with 0 to $3 \mathrm{~min}$ at $50 \% \mathrm{~B}, 3$ to $14 \mathrm{~min}$ at $65 \% \mathrm{~B}$, and 14 to $20 \mathrm{~min}$ at $95 \% \mathrm{~B}$, with a return to initial solvent conditions for the last $10 \mathrm{~min}$ of the gradient ( $30 \mathrm{~min}$ total). Instrument control, data acquisition, and evaluation used MassLynx 4.0 software (Waters Corp.). Identification of target compounds was accomplished by comparing the retention times for the respective MRM transition in a sample with that of a standard analyzed under the same conditions (Table 1). Retention times were considered to match if they were within $\pm 5 \%$ of the compound observed in the calibration standards. ${ }^{13} \mathrm{C}_{6}$-Estradiol was used as the internal standard for all estrogens and resorcyclic acid lactones, and testosterone- $\mathrm{d}_{3}$ was used for quantification of androgens, melengesterol acetate, and progesterone. Laboratory reagent blanks, fortified blanks, fortified matrix samples, and duplicates were each prepared and analyzed at a rate of at least $5 \%$, or 1 for every 20 field samples. Average recovery in fortified blanks $(3 \mathrm{~g}$ clean sand) spiked at $8.3 \mathrm{ng} \mathrm{g}^{-1}$ ranged between $73 \pm 13 \%$ for 4 -androstenedione and $163 \pm 94 \%$ for estriol, with the average recovery of most compounds between 85 and $100 \%$. Using APPI allowed the method to be optimized for androgens and estrogens rather than having two separate ion acquisition methods as required for electrospray ionization. Further details of method development and validation are provided in Snow et al. (2013). The effect of the compost matrix was monitored through the preparation of fortified compost samples (matrix) spiked with $8.3 \mathrm{ng} \mathrm{g}^{-1}$ of each analyte. Recovery of steroids, after subtracting unfortified duplicate matrix samples, averaged between $52 \pm 74 \%$ for $\alpha$-zearalenol and $119 \pm 58 \%$ for $17 \alpha$-trenbolone, with recovery for most compounds averaging between 90 and $110 \%$. The range between laboratory-analyzed sample duplicates was concentration dependent, although it averaged between 0.2 and $5.8 \mathrm{ng} \mathrm{g}^{-1}$. Method detection limits averaged near $0.2 \mathrm{ng} \mathrm{g}^{-1}$ determined by repeated extraction and analysis of a low-level fortified blank (Table 1). Further details of the extraction and analysis are given in Snow et al. (2013).

\section{Results}

The temperature and oxygen content in each pile was monitored over the 76-d composting period (Fig. 1). The compost piles had temperatures ranging from approximately $33^{\circ} \mathrm{C}$ at the start of the study to a maximum of $61^{\circ} \mathrm{C}$ by Day 14 . Thermophilic temperatures $\left(\geq 40^{\circ} \mathrm{C}\right)$ were achieved by Day 6 and sustained for approximately $3 \mathrm{wk}$. The oxygen content within each pile was also measured. The oxygen content within each pile ranged from below detection limits to ambient (20\%), whereas the time-weighted average oxygen content of the compost piles was $10.2 \%$.

Table 1. Mass transitions, retention times, method detection limits, and recovery in the validation test for determination of steroid hormones in manure samples using microwave-assisted solvent extraction and liquid chromatography-tandem mass spectrometry with atmospheric pressure photoionization. $\dagger$

\begin{tabular}{|c|c|c|c|c|}
\hline Analyte & $\begin{array}{l}\text { Mass transition } \\
\text { (precursor }>\text { product ion) }\end{array}$ & Retention time & MASE MDL‡ & Average recovery \\
\hline & & $\min$ & $\mathrm{ng} \mathrm{g}^{-1}$ & $\%$ \\
\hline Estriol & $288>146$ & 7.60 & 0.09 & 103.6 \\
\hline 11-Ketotestosterone & $303>121$ & 8.86 & 0.18 & 87.2 \\
\hline$\beta$-Zearalanol & $305>189$ & 9.34 & 0.22 & 85.4 \\
\hline Androstenedienedione & $285>121$ & 9.58 & 0.16 & 109.9 \\
\hline$\beta$-Zearalenol & $303>285$ & 9.65 & 0.52 & 77.2 \\
\hline $17 \beta$-Trenbolone & $271>199$ & 9.89 & 0.29 & 121.1 \\
\hline$\alpha$-Zearalanol & $305>189$ & 10.29 & 0.12 & 56.1 \\
\hline $17 \alpha$-Trenbolone & $271>253$ & 10.29 & 0.14 & 95.9 \\
\hline $17 \beta$-Estradiol & $255>159$ & 10.52 & 0.34 & 51.8 \\
\hline $17 \alpha$-Ethynylestradiol & $279>133$ & 10.60 & 0.19 & 94.2 \\
\hline 4-Androstenedione & $287>97$ & 10.60 & 1.87 & 185.5 \\
\hline$\alpha$-Zearalenol & $303>285$ & 10.68 & 0.60 & 110.8 \\
\hline Estrone & $271>133$ & 10.68 & 0.49 & 61.8 \\
\hline $17 \alpha$-Estradiol & $255>159$ & 11.00 & 0.20 & 71.1 \\
\hline Testosterone & $289>97$ & 11.21 & 0.26 & 50.9 \\
\hline $17 \alpha$-Hydroxyprogesterone & $331>97$ & 11.55 & 0.07 & 110.7 \\
\hline Epitestosterone & $289>109$ & 12.58 & 0.54 & 135.7 \\
\hline Melengestrol acetate & $397>337$ & 14.08 & 0.71 & 81.8 \\
\hline Progesterone & $315>97$ & 14.23 & 0.59 & 61.0 \\
\hline Androsterone & $273>255$ & 14.79 & 0.58 & 109.6 \\
\hline \multicolumn{5}{|c|}{ Internal standards and surrogates } \\
\hline $17 \beta$-Estradiol- ${ }^{13} \mathrm{C}_{6}$ & $261>159$ & 10.52 & & \\
\hline Testosterone-d5 & $294>100$ & 11.20 & & \\
\hline$\alpha$-Methyltestosterone & $303>97$ & 12.10 & & \\
\hline
\end{tabular}

† Data from Snow et al. (2013).

‡ Microwave-assisted solvent extraction method detection limit. 

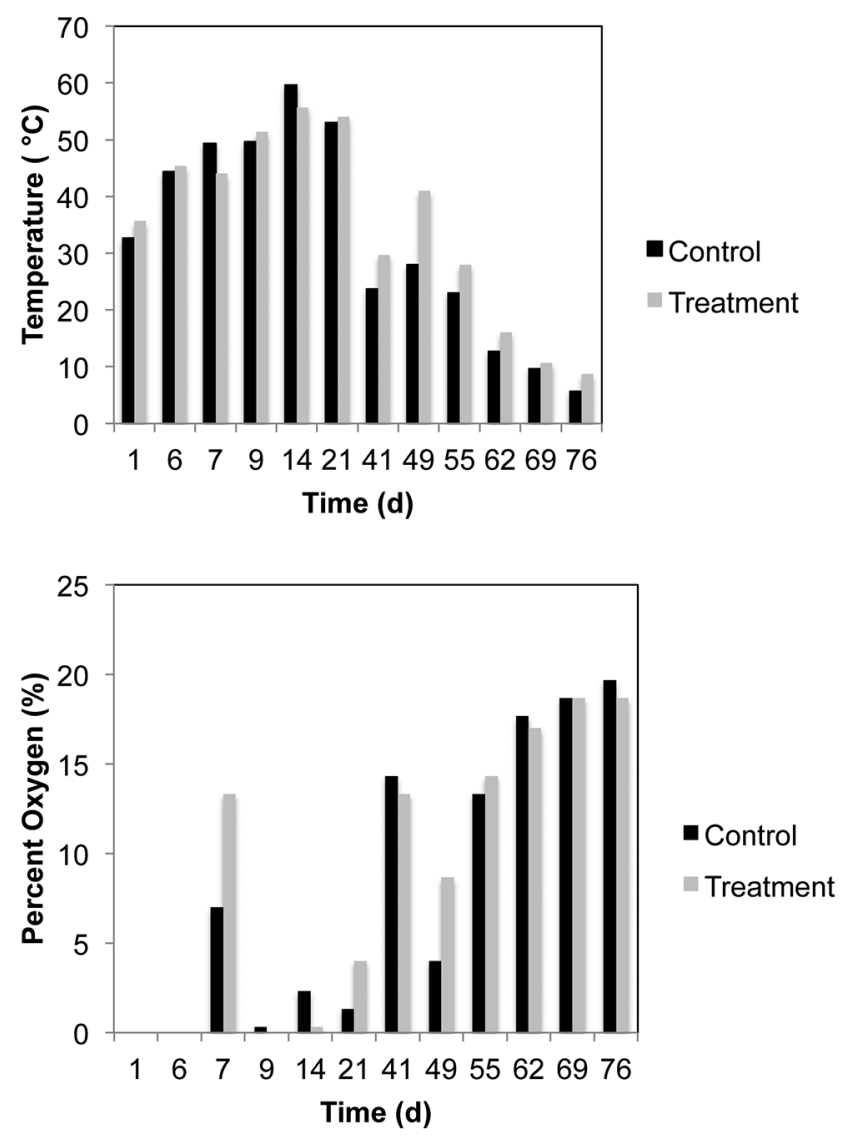

Fig. 1. Temperature and oxygen content in the compost piles.

Table 2 shows the initial steroid hormone concentrations detected in the initial control manure collected from unimplanted animals and treatment manure collected from animals receiving growth promotants and feed additives. Testosterone, 4-androstenedione, androsterone, $17 \beta$-estradiol, estrone, and progesterone were detected in treatment and control manures at concentrations ranging from 1.1 to 69 ng $\mathrm{g}^{-1}$ dry weight compost. Four additional compounds were detected in the treatment manure only: $17 \alpha$-estradiol, $17 \beta$-trenbolone, $\alpha$-zearalanol, and melengesterol acetate. Five compounds (estriol, 17 $\alpha$-trenbolone, $\alpha$-zearalenol, $\beta$-zearalenol, and $17 \alpha$-hydroxyprogesterone) were not detected in either the control or treatment manure. The total initial steroid concentration in the treatment manure $\left(317 \mathrm{ng} \mathrm{g}^{-1}\right.$ dry weight) was higher than that measured in the control manure (104.6 $\mathrm{ng} \mathrm{g}^{-1}$ dry weight). We believe that the higher initial steroid concentrations in the treatment manure are related to the exogeneous steroids administered to these animals (BarteltHunt et al., 2012). It has been demonstrated previously that levels of 173 -estradiol are higher in cattle implanted with trenbolone acetate implants (Henricks et al., 1982).

Figures 2 and 3 show the occurrence of steroids in compost piles as a function of time for the control manure and treatment manure, respectively. For the treatment and control manure samples, the concentration of androsterone decreased over time and was not detected in compost samples at the end of the 76-d study period. 4-Androsterone was also detected in treated and control compost piles at approximately $10 \mathrm{ng} \mathrm{g}^{-1}$ dry weight compost, and the concentration remained relatively
Table 2. Initial steroid hormone concentration in compost piles.

\begin{tabular}{lcc}
\hline \multirow{2}{*}{ Steroid hormone } & \multicolumn{2}{c}{ Concentration } \\
\cline { 2 - 3 } & \multicolumn{1}{c}{ Control } & \multicolumn{1}{c}{ Treatment } \\
\cline { 2 - 3 } Testosterone & $1.3 \pm 0.60$ & $2.3 \pm 1.2$ \\
4-Androstenedione & $12.5 \pm 1.9$ & $14.6 \pm 2.3$ \\
Androsterone & $35.9 \pm 10.6$ & $69 \pm 23$ \\
$17 \alpha$-Estradiol & $\mathrm{ND}$ & $4.7 \pm 1.4$ \\
$17 \beta$-Estradiol & $1.1 \pm 0.49$ & $7.3 \pm 2.4$ \\
Estrone & $24 \pm 8.0$ & $150 \pm 62$ \\
Estriol & $\mathrm{ND} \dagger$ & $\mathrm{ND}$ \\
$17 \alpha$-Trenbolone & $\mathrm{ND}$ & $\mathrm{ND}$ \\
$17 \beta$-Trenbolone & $\mathrm{ND}$ & $52 \pm 15$ \\
$\alpha$-Zearalenol & $\mathrm{ND}$ & $\mathrm{ND}$ \\
$\beta$-Zearalenol & $\mathrm{ND}$ & $\mathrm{ND}$ \\
$\alpha$-Zearalanol & $\mathrm{ND}$ & $4.6 \pm 2.5$ \\
Melengesterol acetate & $\mathrm{ND}$ & $1.4 \pm 0.35$ \\
Progesterone & $29.8 \pm 8.9$ & $11.3 \pm 2.2$ \\
$17 \alpha$-Hydroxyprogesterone & $\mathrm{ND}$ & $\mathrm{ND}$ \\
\hline
\end{tabular}

† Not determined.

constant over the study period. In the treated compost pile, the concentration of estrone was $150 \mathrm{ng} \mathrm{g}^{-1}$ dry weight compost initially but decreased to less than $10 \mathrm{ng} \mathrm{g}^{-1}$ dry weight compost by $9 \mathrm{~d}$. In the control compost pile, the initial concentration of estrone was $24 \mathrm{ng} \mathrm{g}^{-1}$ dry weight compost, and estrone concentrations decreased more gradually, with a final average estrone concentration of $10 \mathrm{ng} \mathrm{g}^{-1} \mathrm{dry}$ weight compost by the end of the study period. All other estrogens were detected at concentrations $\leq 7 \mathrm{ng} \mathrm{g}^{-1}$ dry weight compost in the treated and control compost piles. Progesterone was detected initially in the treatment and control compost piles at concentrations of 11 and $30 \mathrm{ng} \mathrm{g}^{-1}$, respectively. In the control compost piles, the progesterone concentration decreased from $30 \mathrm{ng} \mathrm{g}^{-1}$ initially to approximately $10 \mathrm{ng} \mathrm{g}^{-1}$ by Day 72 . In the treated compost pile, progesterone concentrations remained relatively constant over the study period. Limited detections of $17 \alpha$-hydroxyprogesterone were found in the control and in the treatment compost over the study period. The fusarium metabolite and implant $\alpha$-zearalanol was initially detected in the control compost at a concentration of $5 \mathrm{ng} \mathrm{g}^{-1}$ and was not initially detected in the treatment compost.

\section{Discussion}

Estrone was the dominant estrogen detected in the control and treated manure compost piles at the start of the experiment. $17 \beta$-Estradiol was detected in the compost initially at average concentrations ranging from 1.1 to 7.3 $\mathrm{ng} \mathrm{g}^{-1}$ dry weight compost but was not routinely detected in subsequent sampling events. In a previous publication by the authors, the concentration of 173 -estradiol in the manure and cattle feedlot surface soil that was used to generate the compost piles in the current study was reported to range between 1.2 and $19 \mathrm{ng} \mathrm{g}^{-1}$ dry matter (Bartelt-Hunt et al., 2012). This indicated that degradation of $17 \beta$-estradiol occurred after the manure and soil was scraped from the pens but before the initial sampling event for the compost piles. Results from this study agree with a previous study of swine manure composting 

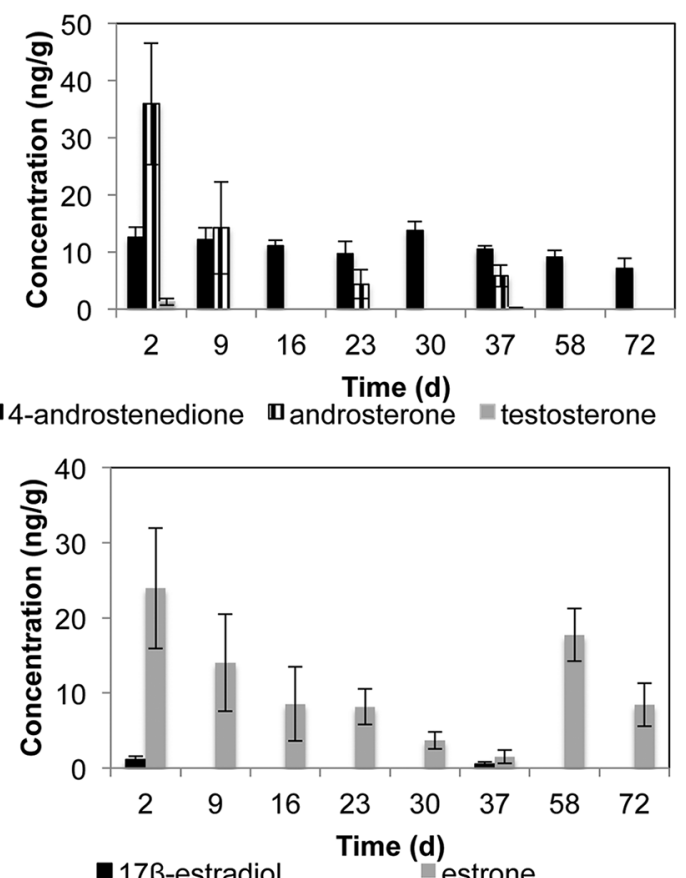

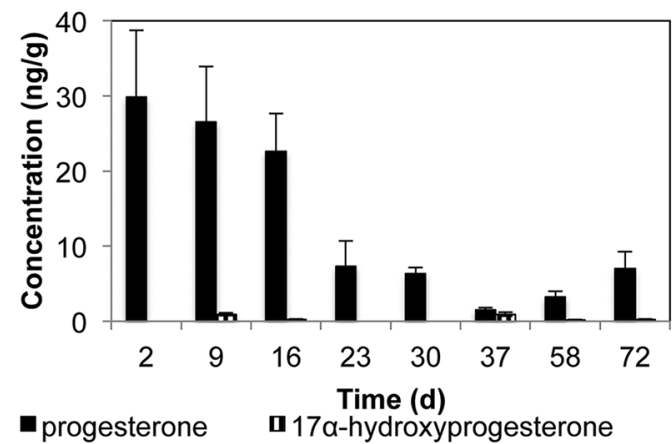

progesterone $\mathbf{\square} 17$ a-hydroxyprogesterone

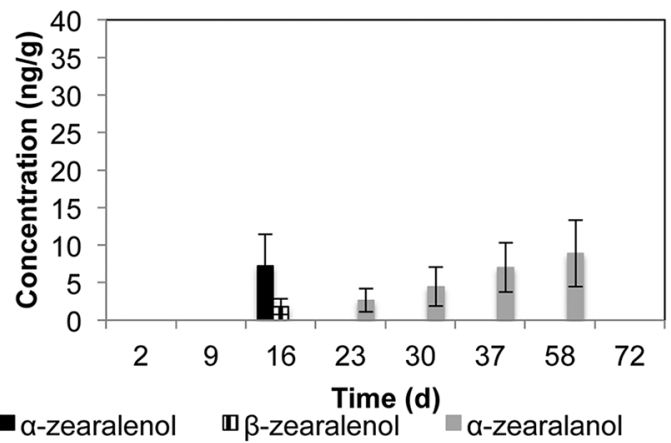

Fig. 2. Concentration of steroid hormones in composting piles containing manure from animals not treated with growth promotants. Concentrations expressed in $\mathrm{ng} \mathrm{g}^{-1}$ dry material. Error bars represent $\pm 1 \mathrm{SE}$.

published by Derby et al. (2011), which found estrone to be the dominant estrogen in swine manure compost piles. In the current study, the final estrone concentration was 95 and $36 \%$ of the initial estrone concentration present in the starting manure in the treated and control compost piles, respectively. In the compost piles containing manure from treated animals, estrone concentrations decreased gradually over the first $30 \mathrm{~d}$, whereas in the control compost piles, estrone decreased

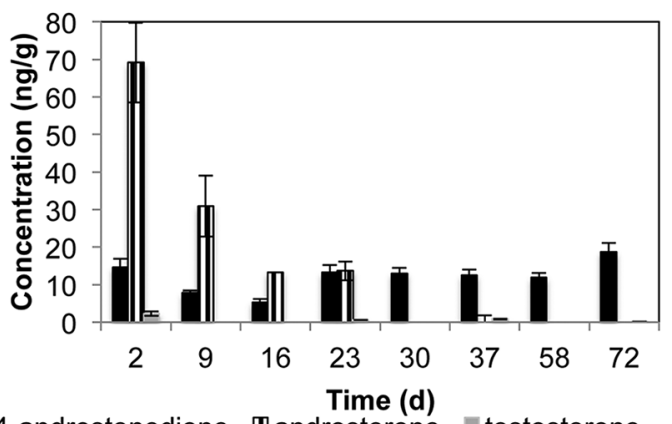

-4-androstenedione mandrosterone $=$ testosterone

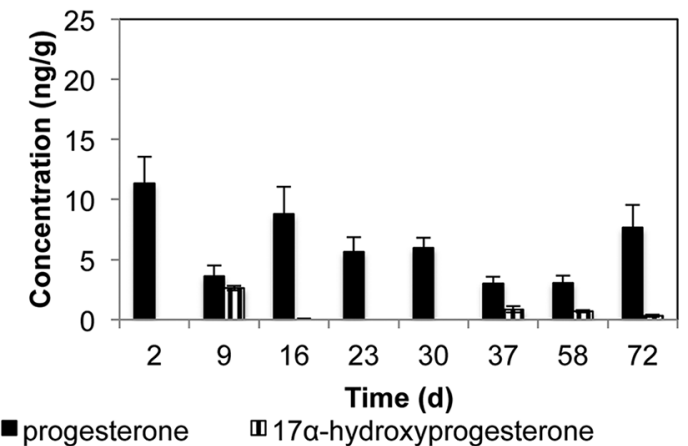

substantially until Day 9 and then remained at concentrations $<10 \mathrm{ng} \mathrm{g}^{-1}$ dry weight compost. These results are similar to those observed by Derby et al. (2011) in a study of swine manure composting, which found that estrone concentrations decreased until Day 36 and then remained relatively constant at a concentration of $2 \mathrm{ng} \mathrm{g}^{-1}$. Taken together, these results indicate that composting processes do not completely degrade or mineralize estrone.
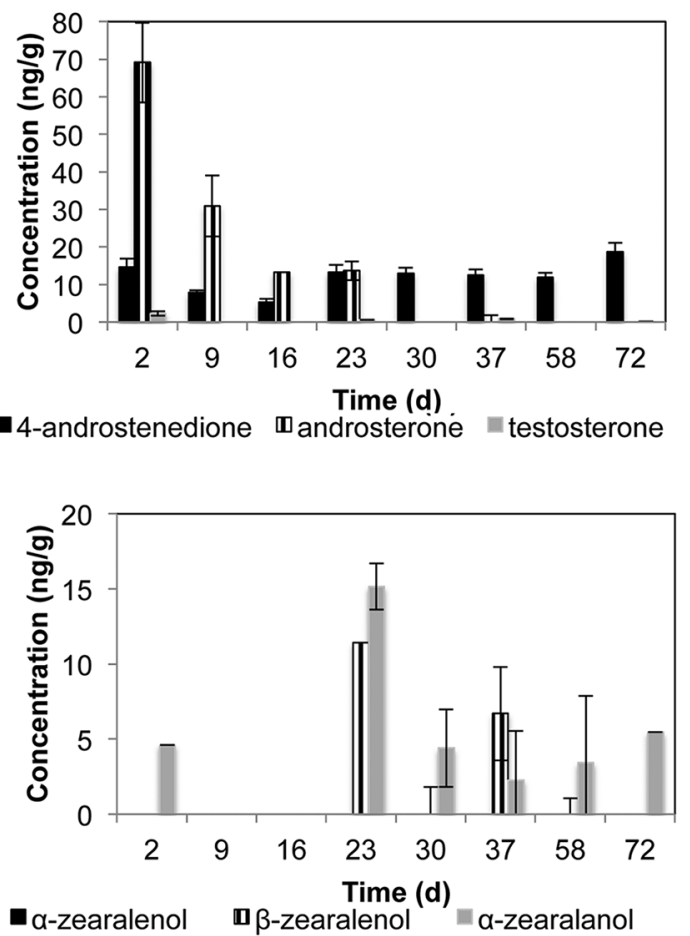

Fig. 3. Concentration of steroid hormones in composting piles containing manure from animals treated with growth promotants. Concentrations expressed in $\mathrm{ng} \mathrm{g}^{-1}$ dry material. Error bars represent $\pm 1 \mathrm{SE}$. 
Testosterone was detected in the starting manure in the compost piles at relatively low concentrations $\left(<2 \mathrm{ng} \mathrm{g}^{-1}\right.$ dry weight compost). This is in contrast to a previous study that reported initial testosterone concentrations in poultry litter compost piles of $115 \mathrm{ng} \mathrm{g}^{-1}$ compost dry weight (Hakk et al., 2005). In the present study, the androgens 4-androstenedione and androsterone were detected more frequently and at higher concentrations than testosterone in the compost piles. Androsterone was completely degraded in the control and treated compost piles by 37 and $30 \mathrm{~d}$, respectively. In contrast, 4-androstenedione was more recalcitrant and 4-androstenedione concentrations remained relatively stable over the 76-d study period in the treated and control manures. Although testosterone has been previously shown to degrade during poultry litter manure composting (Hakk et al., 2005), to our knowledge previous studies have not evaluated the fate of testosterone metabolites in manure composting. Because these metabolites are still endocrine active, the fate of testosterone metabolites in composted manure is of environmental and public health importance.

A first-order decay model was used to estimate steroid hormone dissipation half-lives in manure. Steroid concentration data that fit a first-order decay model $\left(R^{2} \geq 0.5\right)$ is presented in Fig. 4. The predicted half-lives for steroids in composted control manure are: $69 \mathrm{~d}$ for 4-androstenedione $(\mathrm{k}$ $\left.=0.011 \mathrm{~d}^{-1}\right), 9.9 \mathrm{~d}$ for androsterone $\left(\mathrm{k}=0.0712 \mathrm{~d}^{-1}\right), 9.9 \mathrm{~d}$ for estrone $\left(\mathrm{k}=0.0744 \mathrm{~d}^{-1}\right)$, and $23 \mathrm{~d}$ for progesterone $(\mathrm{k}=$ $\left.0.0306 \mathrm{~d}^{-1}\right)$. Calculated half-lives in composted treatment
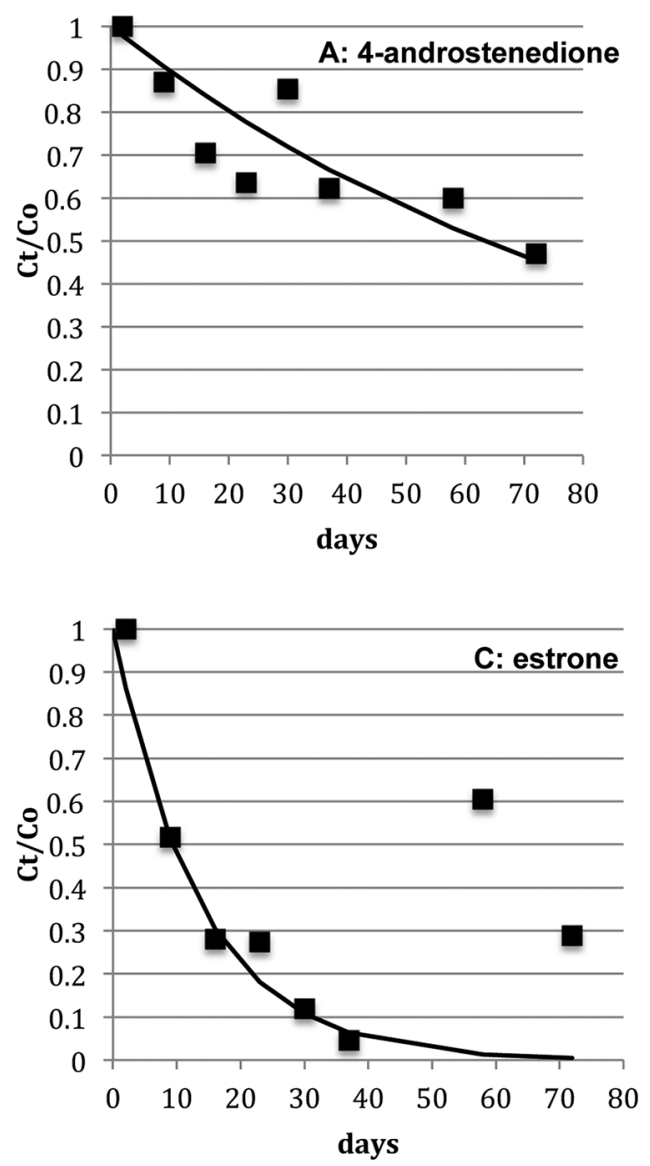

manure were $7.7 \mathrm{~d}\left(\mathrm{k}=0.0903 \mathrm{~d}^{-1}\right)$ for androsterone and $35 \mathrm{~d}\left(\mathrm{k}=0.0297 \mathrm{~d}^{-1}\right)$ for progesterone. For androsterone and progesterone, concentrations measured in control and treatment manure could be modeled using a first-order decay equation, and the predicted half-lives generally agreed well between control and treatment manures. Limited halflife estimates have been reported for steroids in manure composting. Hakk et al. (2005) reported decay rates of $0.01 \mathrm{~d}^{-1}$ for $17 \beta$-estradiol and $0.015 \mathrm{~d}^{-1}$ for testosterone in composted poultry manure. For other compounds, first-order decay equations did not fit steroid degradation data collected in this study. This may imply that, in addition to steroid degradation, other microbial processes occurring during manure composting result in steroid production or synthesis. Previous work has suggested that microbial and reversible transformation pathways of many steroids and related compounds can lead to in situ production of parent compounds or to the release of a previously unextractable steroid fraction (Mansell et al., 2011; Bartelt-Hunt et al., 2012).

This study is the first to report the fate of progesterone in animal manure composting. In the compost piles containing manure from control animals, progesterone concentrations decreased by $76 \%$ to less than $10 \mathrm{ng} \mathrm{g}^{-1}$ dry weight compost by Day 23 but remained relatively constant from Day 23 to Day 72. In the treated compost piles, the initial progesterone concentration was lower $\left(11.3 \mathrm{ng} \mathrm{g}^{-1} \mathrm{dry}\right.$ weight compost), and progesterone concentrations remained relatively stable over the $76-\mathrm{d}$ study period. A corresponding
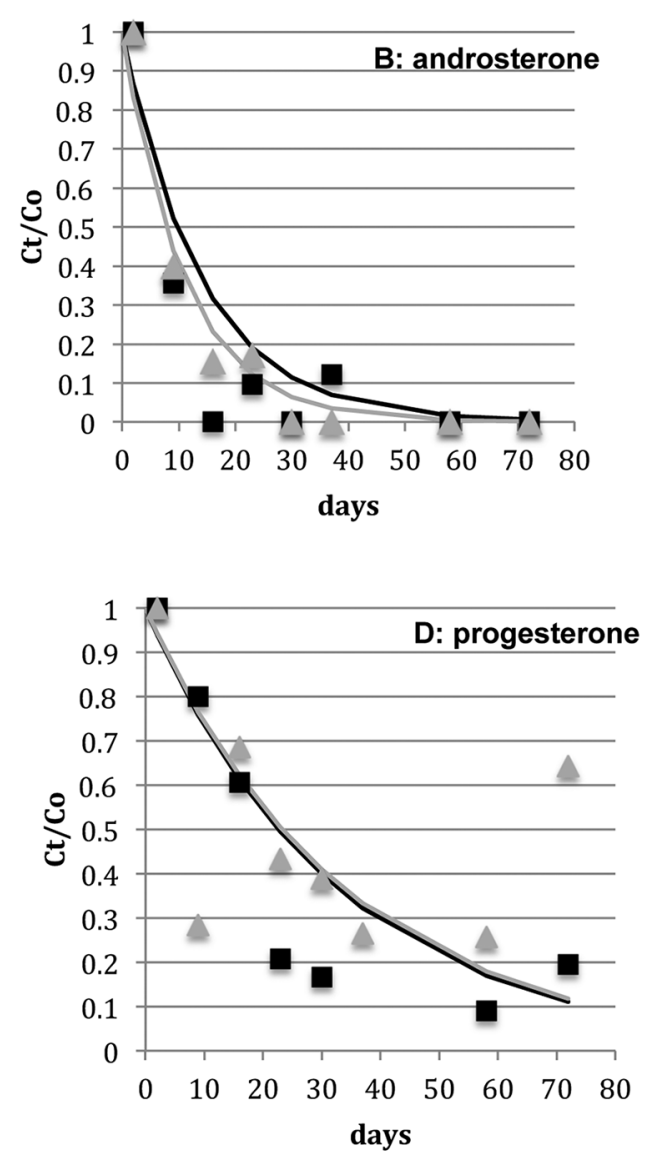

Fig. 4. Degradation of steroid hormones in control (squares) and treatment (triangles) manure. Lines represent first-order decay model results. 
increase in $17 \alpha$-hydroxyprogesterone was not observed with decreases in progesterone concentrations, indicating that $17 \alpha$-hydroxyprogesterone may not be a primary metabolite formed from progesterone degradation in compost. Previous studies have documented 4-androstenedione and androstanedienedione production from progesterone by soil bacteria, and bacterial mechanisms for the production of testosterone via progesterone conversion to $17 \alpha$-hydroxyprogesterone and androstenedione have been identified (Carlström, 1967; Wadhwa and Smith, 2000; Jenkins et al., 2004). It is possible that the stable 4 -androstenedione concentrations observed in compost piles in this study may be due to oxidation of androstenedione and/or formation of 4-androstenedione from progesterone. Two recent studies of steroid occurrence in cattle feedlot runoff also hypothesized that the presence of androgens in runoff may be due to progesterone degradation in manure or feedlot soils (Mansell et al., 2011; Bartelt-Hunt et al., 2012).

$\alpha$-Zearalanol was administered as a growth promotant to cattle in the treated group; however, $\alpha$-zearalanol, $\alpha$-zearalenol, and $\beta$-zearalenol were detected starting on Day 16 in the control compost piles and starting on Day 23 for the treated compost piles. As in a previous study by the authors, we hypothesize here that the occurrence of $\alpha$-zearalanol in manure is likely due to excretion from implanted cattle and/ or due to the metabolism of zearalenone produced by fusarium mold, which is commonly found in fermented corn (BarteltHunt et al., 2012). The sporadic detection of these compounds in samples obtained from treated and control manure compost piles makes it difficult to evaluate their specific source or their persistence in compost. In compost piles containing manure from control animals, $\alpha$-zearalanol was detected on Day 23, and the concentration increased gradually through Day 58. This study provides the first documentation of the occurrence of the growth promotant $\alpha$-zearalanol in compost and provides initial evidence that concentrations of $\alpha$-zearalanol may increase during composting.

Taken together, the total amounts of steroids present in the treated and control manures at the end of the 76-d study period were 42 and $23 \mathrm{ng} \mathrm{g}^{-1}$ dry weight compost, respectively. This represents an overall reduction in steroid concentration of $79 \%$ (treatment manure) and 87\% (control manure).

This study represents the first field study to evaluate the fate of steroid hormones during beef cattle manure composting. Results from this study generally agree with previous studies conducted on swine and poultry litter composting. The primary estrogen detected in the cattle manure compost piles was estrone. Estrone concentrations decreased initially and then remained relatively stable throughout the remainder of the study period. Testosterone was not detected in the initial cattle manure samples, but other androgens, including 4 -androstenedione and androsterone, were detected in cattle manure compost samples. 4-Androstenedione was found to persist in cattle manure composting throughout the 76-d study period. Additional steroid hormones detected in this study that were not previously evaluated in animal manure composting included progesterone, $17 \alpha$-hydroxyprogesterone, $\alpha$-zearalanol, $\alpha$-zearalenol, and $\beta$-zearalenol. Our results indicate that although parent steroid concentrations may decrease during animal manure composting, the occurrence and behavior of steroid and other metabolites should be evaluated to more fully understand the potential biologic activity of composted animal manures. When summed together, steroid hormone concentrations in beef cattle manure decreased by up to $87 \%$ after composting. Although some individual steroids were found to remain stable over the study period, overall, composting is a viable manure management strategy to reduce the concentrations of biologically active steroid hormones in manure before land application of animal manure.

\section{Acknowledgments}

The study was funded in part by a USEPA Science to Achieve Results (STAR) award no. R833423.

\section{References}

Arikan, O.A., W. Mulbry, and C. Rice. 2009. Management of antibiotic residues from agricultural sources: Use of composting to reduce chlortetracycline residues in beef manure from treated animals. J. Hazard. Mater. 164:483489. doi:10.1016/j.jhazmat.2008.08.019

Bao, Y., Q. Zhou, L. Guan, and Y. Wang. 2009. Depletion of chlortetracycline during composting of ages and spiked manures. Waste Manag. 29:14161423. doi:10.1016/j.wasman.2008.08.022

Bartelt-Hunt, S.L., D.D. Snow, W.L. Kranz, T.L. Mader, C.A. Shapiro, S.J. van Donk, D.P. Shelton, D.D. Tarkalson, and T.C. Zhang. 2012. Effect of growth promotants on the occurrence of natural and synthetic steroid hormones on feedlot soils and in runoff from beef cattle feeding operations. Environ. Sci. Technol. 46:1352-1360. doi:10.1021/es202680q

Burkholder, J., B. Libra, P. Weyer, S. Heathcote, D. Kolpin, P.S. Thorne, and M. Wichman. 2007. Impacts of waste from concentrated animal feeding operations on water quality. Environ. Health Perspect. 115:308-312. doi: $10.1289 /$ ehp.8839

Camel, V. 2000. Microwave-assisted solvent extraction of environmental samples. TRAC-Tren. Anal. Chem. 19:229-248.

Carlström, K. 1967. Mechanism of the side chain degradation of progesterone by microorganisms. Acta Chem. Scand. 21:1297-1303. doi:10.3891/acta. chem.scand.21-1297

Derby, N.E., H. Hakk, F.X.M. Casey, and T.M. DeSutter. 2011. Effects of composting swine manure on nutrients and estrogens. Soil Sci. 176:91-98. doi: 10.1097/SS.0b013e3182088377

Dutta, S., S. Inamdar, J. Tso, D.S. Aga, and J.T. Sims. 2010. Free and conjugated estrogen exports in surface-runoff from poultry litter amended soil. J. Environ. Qual. 39:1688-1698. doi:10.2134/jeq2009.0339

Fine, D., G. Breidenbach, T. Price, and S. Hutchins. 2003. Quantitation of estrogens in ground water and swine lagoon samples using solidphase extraction, pentafluorobenzyl/trimethylsilyl derivatizations and gas chromatography-negative ion chemical ionization tandem mass spectrometry. J. Chromatogr. A 1017:167-185. doi:10.1016/j. chroma.2003.08.021

Finlay-Moore, O., P.G. Hartel, and M.L. Cabrera. 2000. 17ß-estradiol and testosterone in soil and runoff from grasslands amended with broiler litter. J. Environ. Qual. 29:1604-1610. doi:10.2134/ jeq2000.00472425002900050030x

Gall, H.E., S.A. Sassman, L.S. Lee, and C.T. Jafvert. 2011. Hormone discharges from a Midwest tile-drained agroecosystem receiving animal wastes. Environ. Sci. Technol. 45:8755-8764. doi:10.1021/es2011435

Hakk, H., P. Millner, and G. Larsen. 2005. Decrease in water-soluble $17 \beta$-estradiol and testosterone in composted poultry manure with time. J. Environ. Qual. 34:943-950. doi:10.2134/jeq2004.0164

Hakk, H., and L. Sikora. 2011. Dissipation of 17 $\beta$-estradiol in composted poultry litter. J. Environ. Qual. 40:1560-1566. doi:10.2134/ jeq2010.0538

Henricks, D.M., R.L. Edwards, K.A. Champe, T.W. Gettys, G.C. Skelley, Jr., and T. Gimenez. 1982. Trenbolone, estradiol-17 $\beta$, and estrone levels in plasma and tissues and live weight gains of heifers implanted with trenbolone acetate. J. Anim. Sci. 55:1048-1056.

Hutchins, S., M. White, F. Hudson, and D. Fine. 2007. Analysis of lagoon aamples from different concentrated animal feeding operations for 
estrogens and estrogen conjugates. Environ. Sci. Technol. 41:738-744. doi:10.1021/es062234+

Jenkins, R.L., E.M. Wilson, R.A. Angus, W.M. Howell, M. Kirk, R. Moore, M. Nance, and A. Brown. 2004. Production of androgens by microbial transformation of progesterone in vitro: A model for androgen production in rivers receiving paper mill effluent. Environ. Health Perspect. 112:15081511. doi:10.1289/ehp.7161

Kim, K.-R., G. Owens, Y.S. Ok, W.-K. Park, D.B. Lee, and S.-I. Kwon. 2012. Decline in extractable antibiotics in manure-based composts during composting. Waste Manag. 32:110-116. doi:10.1016/j. wasman.2011.07.026

Kolok, A.S., and M.K. Sellin. 2008. The environmental impact of growth promoters employed by the United States beef cattle industry: History, current knowledge and future directions. Rev. Environ. Contam. Toxicol. 195:1-30.

Labadie, P., A.B. Cundy, K. Stone, M. Andrews, S. Valbonesi, and E.M. Hill. 2007. Evidence for the migration of steroidal estrogens through river bed sediments. Environ. Sci. Technol. 41:4299-4304. doi:10.1021/es063062j

Mansell, D.S., R.J. Bryson, T. Harter, J.P. Webster, E.P. Kolodziej, and D.L. Sedlak. 2011. Fate of endogeneous steroid hormones in steer feedlots under simulated rainfall-induced runoff. Environ. Sci. Technol. 45:88118818. doi:10.1021/es202072f

Matejícek, D., P. Houserová, and V. Kubán. 2007. Combined isolation and purification procedures prior to the high-performance liquid chromatographic-ion-trap tandem mass spectrometric determination of estrogens and their conjugates in river sediments. J. Chromatogr. A. 1171:80-89. doi:10.1016/j.chroma.2007.09.053

Nichols, D.J., T.C. Daniel, P.A. Moore, D.R. Edwards, and D.H. Pote. 1997. Runoff of estrogen hormone 17 beta-estradiol from poultry litter applied to pasture. J. Environ. Qual. 26:1002-1006. doi:10.2134/ jeq1997.00472425002600040011x

Ramaswamy, J., S.O. Prasher, R.M. Patel, S.A. Hussain, and S.F. Barrington. 2010. The effect of composting on the degradation of a veterinary pharmaceutical. Bioresour. Technol. 101:2294-2299. doi:10.1016/j. biortech.2009.10.089

Seki, M., S. Fujishima, T. Nozaka, M. Maeda, and K. Kobayashi. 2006. Comparison of response to $17 \beta$-trenbolone among three small fish species. Environ. Toxicol. Chem. 25:2742-2752. doi:10.1897/05-647R.1

Snow, D.D., T. Damon-Powell, S. Onanong, and D.A. Cassada. 2013. Sensitive and simplified analysis of natural and synthetic steroids in water and solids using on-line solid phase extraction and microwave-assisted solvent extraction coupled to liquid chromatography tandem mass spectrometry atmospheric pressure photoionization. Anal. Bioanal. Chem. 405:17591771. doi: $10.1007 /$ s00216-012-6572-8

Tetreault, G., C.J. Bennett, K. Shires, B. Knight, M.R. Servos, and M.E. McMaster. 2011. Intersex and reproductive impairment of wild fish exposed to multiple wastewater discharges. Aquat. Toxicol. 104:278-290. doi:10.1016/j.aquatox.2011.05.008

U.S. Environmental Protection Agency. 2004. Risk management evaluation for concentrated animal feeding operations, EPA-600-R-04-042. Office of Research and Development, National Risk Management Research Laboratory, Cincinnati, $\mathrm{OH}$.

Wadhwa, L., and K.E. Smith. 2000. Progesterone side-chain cleavage by Bacillus sphaericus. FEMS Microbiol. Lett. 192:179-183. doi:10.1111/j.1574-6968.2000.tb09379.x

Zheng, W., S.R. Yates, and S.A. Bradford. 2008. Analysis of steroid hormones in a typical dairy waste disposal system. Environ. Sci. Technol. 42:530-535. doi:10.1021/es071896b 